\title{
CAMP in the pituitary: an old messenger for multiple signals
}

\author{
Erika Peverelli', Giovanna Mantovani ${ }^{1}$, Andrea G Lania ${ }^{2}$ and Anna Spada ${ }^{1,+}$ \\ 'Endocrine Unit, Department of Clinical Sciences and Community Health, Fondazione IRCCS Ca' Granda \\ Ospedale Maggiore Policlinico ${ }^{2}$ Endocrine Unit, IRCCS Humanitas Clinical Institute, Rozzano, \\ University of Milan, Milan, Italy \\ ${ }^{\dagger}$ A Spada is now at Fondazione IRCCS Ca' Granda Ospedale Maggiore Policlinico, Unitá Operativa di Endocrinologia \\ e Diabetologia, Padiglione Granelli via F. Sforza 35, 20122 Milano, Italy
}

Correspondence should be addressed to A Spada

Email anna.spada@unimi.it

\begin{abstract}
The cyclic nucleotide CAMP is a universal regulator of a variety of cell functions in response to activated G-protein coupled receptors. In particular, CAMP exerts positive or negative effects on cell proliferation in different cell types. As demonstrated by several in vitro studies, in somatotrophs and in other endocrine cells, CAMP is a mitogenic factor. In agreement with this notion, it has been found that the mutations of genes coding for proteins that contribute to increases in the CAMP signaling cascade may cause endocrine tumor development. This review will discuss the central role of CAMP signaling in the pituitary, focusing on the CAMP pathway alterations involved in pituitary tumorigenesis, as well as on poorly investigated the aspects of CAMP cascade, such as crosstalk with the ERK signaling pathway and new cAMP effectors.
\end{abstract}
Key Words
- CAMP
- GNAS1
- imprinting
- pituitary tumors

\section{Introduction}

The cyclic nucleotide cAMP was discovered in 1958 as the factor mediating the effect of epinephrine on glycogenolysis by Dr Earl W Sutherland who obtained a Nobel prize in 1971 for these discoveries. This was the first of three Nobel prizes recognizing research on this pathway.

cAMP, thus became the first member of the family of 'second messengers', is now been recognized as a universal regulator of a myriad of cell functions. A schematic view of the cAMP signaling cascade is shown in Fig. 1. cAMP is produced from ATP by adenylyl cyclase, a large family of proteins including ten isoforms encoded by ten different genes and classified in five families (reviewed by Sunahara $\&$ Taussig (2002)). Mouse pituitaries express mRNA for adenylyl cyclase isoforms II, III, VI, and VII (Pronko et al. 2010), depending on the cell type. In particular, GHproducing cells $\left(\mathrm{GH}_{2} \mathrm{C}_{1}\right.$ cells) mainly contain adenylyl cyclase types I, III (calcium-calmoduline sensitive), and VI, whereas cells predominantly secreting PRL express adenylyl cyclase types II, IV, and VI (GH3 and GH4C1 cells) and type VIII (GH3B6 cells) (Paulssen et al. 1994, Wachten et al. 2010). In contrast, adenylyl cyclase IX, but not II and VI, was detected in corticotrope cells (Antoni et al. 2003).

Adenylyl cyclases are regulated by heterotrimeric guanine nucleotide-binding proteins ( $G$ proteins), composed of three different subunits $(\alpha, \beta$, and $\gamma)$ and activated by seven transmembrane, G-protein-coupled receptors (GPCRs). The $\alpha$ subunit binds guanine nucleotides and acts as GTPase. Activated GPCRs facilitate the exchange of GTP for GDP on $\alpha$ subunit, that becomes active, dissociates from $\beta \gamma$ and then regulates the effector proteins. Among these, adenylyl cyclase is activated by the stimulatory G protein (Gs). In pituitary cells, Gs plays a central role in mediating cAMP pathway activation after

Published by Bioscientifica Ltd 


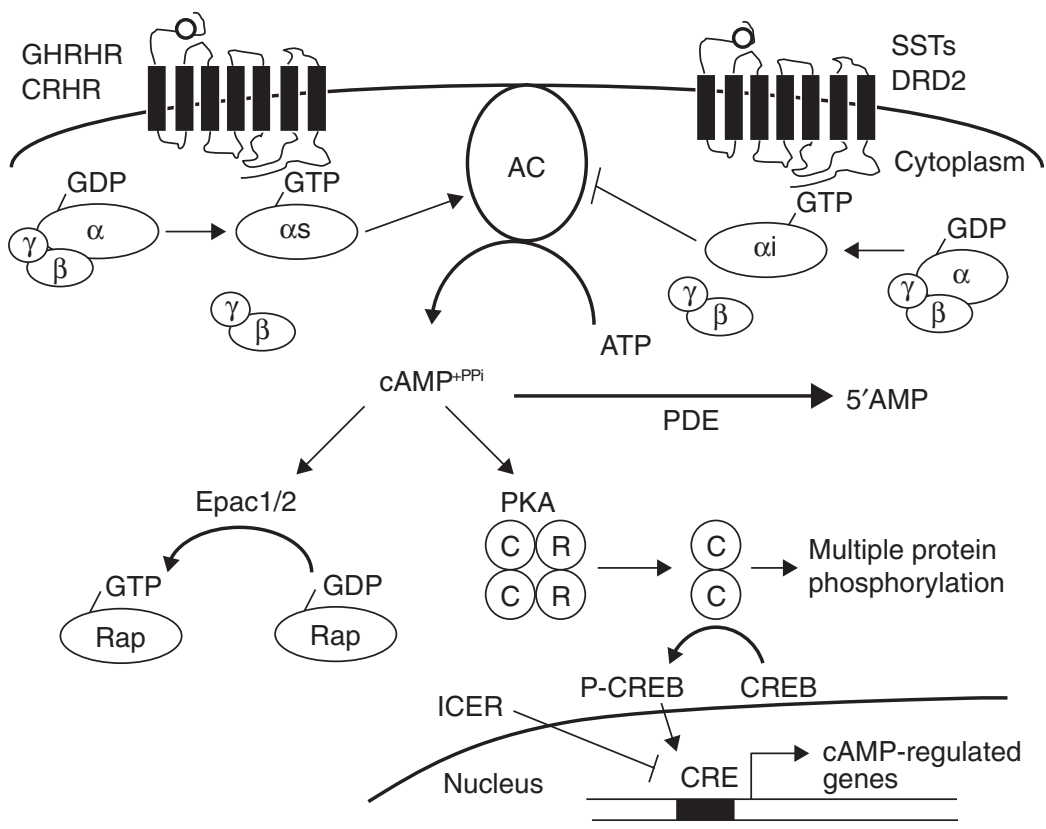

\section{Figure 1}

Schematic representation of CAMP pathway. CAMP is produced from ATP by adenylyl cyclases that are positively or negatively regulated by stimulatory or inhibitory $\mathrm{G}$ proteins respectively. $\mathrm{G}$ proteins are composed of three distinct subunits, and the $\alpha$ subunit contains high-affinity binding sites for guanine nucleotide and has intrinsic GTPase activity. The GDP-bound form binds tightly to $\beta \gamma$ and is inactive, whereas the GTP-bound form dissociates from $\beta \gamma$ and is the active form. GPCRs cause the activation of G proteins by facilitating the exchange of GTP for GDP on the $\alpha$ subunit. CAMP is degraded to AMP by PDEs. The CAMP effector protein kinase A (PKA) is a tetrameric serine/threonine kinase consisting of a regulatory subunit $(R)$ dimer and two catalytic (C) subunits. PKA is activated by the rise in CAMP that, by binding

stimulation by hormones, such as growth hormone (GH) and corticotroph-releasing hormone (CRH).

The best known cAMP downstream effector is protein kinase A (PKA). This serine/threonine kinase is a tetrameric enzyme composed of two regulatory (R) and two catalytic (C) subunits. The R subunit exists in two isoforms, RI and RII, which give rise to two PKA isozymes (PKA I and II). Binding of cAMP to each $\mathrm{R}$ subunit induces dissociation of $\mathrm{C}$ subunit that becomes free to phosphorylate their substrates (Skalhegg \& Tasken 2000).

cAMP is degraded to AMP by cyclic nucleotide phosphodiesterases (PDEs) that play a major role in the regulation of intracellular cAMP levels. Up to now, 11 subfamilies of PDEs, which differ in structure, enzymatic properties, sensitivity to inhibitors, and expression, have been characterized, each subfamily including distinct genes that, in turn, generate several transcripts by alternative splicing and/or the use of multiple promoters (Bender \& Beavo 2006). Among these different isoforms PDE1A, PDE2A, PDE4(A,B,C,D), PDE8B, and PDE11A are both high-affinity cAMP-binding sites of each $\mathrm{R}$ subunit, leads to the release of active $\mathrm{C}$ subunits that phosphorylate their substrates, including the nuclear transcription factor CREB. The repressor transcription factor inducible CAMP early repressor (ICER), positively regulated by CAMP signaling, competes with the binding of CREB to CREs, and may inhibit the transcription of several CAMP responsive genes. Epac1/2 are exchange proteins directly activated by CAMP that mediates several cAMP effects by acting as guanine-nucleotide exchange factors for Ras-proximate 1 and 2 (Rap1 and 2). GHRHR, growth hormone-releasing hormone receptor; CRHR, corticotrophin-releasing hormone receptor; DRD2, dopamine receptor D2; SST, somatostatin receptor; PDE, phosphodiesterase; AC, adenylyl cyclase.

the most expressed in the pituitary (Michibata et al. 2001, Persani et al. 2001, Peverelli et al. 2009a, Stephenson et al. 2009, Lennox et al. 2011). PDEs are activated by cAMP both by phosphorylation and gene expression induction.

Consistent with the central role played by cAMP in the regulation of cell proliferation in endocrine tissues, mutations of genes involved in the cAMP signaling pathway and resulting either in the constitutive activation of cAMP formation or in increased cAMP signal transduction have been identified as a cause of endocrine neoplasia.

\section{Lessons from human diseases: alterations of cAMP signaling}

\section{Genetic and epigenetic alterations in the Gs $\alpha$ gene (GNAS)} in $\mathrm{GH}$-secreting adenomas

The first mutational change associated with pituitary tumors was identified in the gene encoding the $\alpha$ subunit of Gs (GNAS1) (GNAS). This gene maps to chromosome

Published by Bioscientifica Ltd. 
20q13 and contains 13 exons (Fig. 2). Amino acid substitutions in exons 8 and 9, replacing either Arg 201 with Cys, His, or Ser; or Gln 227 with Arg or Leu, were found in a subgroup of GH-secreting pituitary tumors (Vallar et al. 1987, Landis et al. 1989, Clementi et al. 1990, Lyons et al. 1990). These adenomas showed high activity of adenylyl cyclase and cAMP levels could not be further increased by specific and nonspecific compounds. The mutations were found to occur at two sites critical for GTP-ase activity, thus maintaining the adenylyl cyclase system in a permanently turned-on state by preventing hydrolysis of GTP. It is of interest to note that the residue Arg 201 is the target of cholera toxin that, by ADP-ribolsylation, abolished the GTPase activity of Gs, with a consequent constitutive activation. Functional studies on cell lines transfected with mutant Gs $\alpha$ demonstrated that activating mutations increase proliferation of selected cell types in which cAMP is mitogenic (Zachary et al. 1990, Muca \& Vallar 1994, Ham et al. 1997). Recently an in vivo study has demonstrated that the activating mutation Arg201Cys in GNAS cooperates with inactivation of adenomatous polyposis coli to promote intestinal tumorigenesis in mice through activation of Wnt and ERK1/2 MAPK pathways (Wilson et al. 2010).

These data identify Gs $\alpha$ as a product of a protooncogene, converted into an oncogene ( $g s p)$ in those cells in which cAMP represents a mitogenic signal.

Somatic activating mutations in GNAS are found in $30-40 \%$ of GH-secreting pituitary tumors, and less commonly in other endocrine tumors such as toxic thyroid adenomas, hyperfunctioning adrenal tumors, and Leydigiomas.

When these mutations occur as an early postzygotic event, they cause the McCune-Albright syndrome (MAS, MIM\# 174800). This sporadic disease affects the bones (polyostotic fibrous dysplasia), the skin (café-au-lait spots), and several endocrine tissues (autonomous hyperfunction), such as gonads, pituitary, thyroid, and adrenal cortex (Weinstein et al. 1991, Schwindinger et al. 1992). Activating mutations in the GNAS1 gene, in particular Arg 201, have been detected in all patients with MAS. Mutant Gs $\alpha$ is expressed in the affected endocrine organs as well as in tissues not classically involved in MAS, the highest proportion of mutant alleles being found in regions of abnormal proliferation, with a mosaic distribution consistent with the hypothesis that the cause of this syndrome is due to a GNAS somatic mutation arising very early in embryogenesis. In contrast, when mutation occurs later, it may cause focal diseases, such as acromegaly and toxic thyroid adenomas.

The GNAS1 locus shows a highly complex imprinted expression pattern. Genomic imprinting is the epigenetic phenomenon by which one allele (maternal or paternal), either during embryogenesis or the post-natal period, is subjected to a partial or total loss of expression (Bartolomei \& Tilgham 1997). Upstream of Gs $\alpha$ exon 1, are located alternative promoters that are oppositely imprinted, giving rise to different mRNAs including extra large $\alpha$ s-like protein (XLas), XL-exon1 (ALEX), neuroendocrine secretory protein 55 (NESP55), exon A/B (1A), and antisense transcripts AS (Nespas) (Fig. 2; reviewed by Bastepe \& Juppner (2005)).

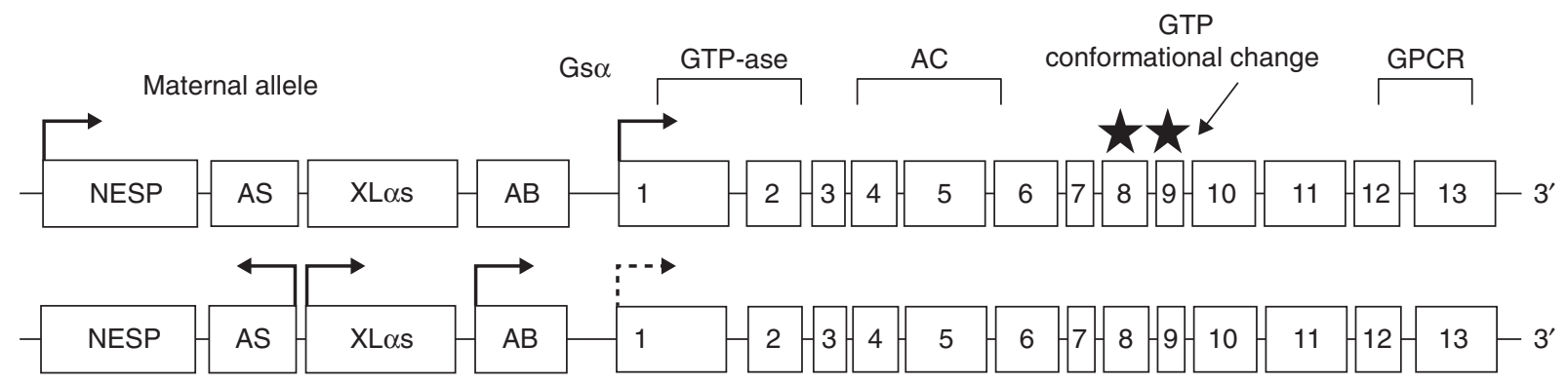

Paternal allele

\section{Figure 2}

Genomic organization and imprinting of the human GNAS1 locus. The maternal and paternal alleles of GNAS are shown. Active promoters are represented by arrows in the direction of transcription. The figure shows the alternative first exons which splice into exon 2, generating different transcripts: Gs $\alpha$, XLas, a second alternative gene product encoded by the XL-exon1 (ALEX), NESP55, exon A/B, which generates untranslated transcripts of unknown function with a similar pattern of expression to that of Gs $\alpha$ and antisense transcripts (AS). The dashed line at the paternal Gs $\alpha$ promoter indicates tissue-specific imprinting of the gene. Exons 2-13 are common to all transcripts, even if they are not translated in NESP55. The figure also shows the Gs $\alpha$ activating mutations (stars) detected in this gene. The diagram is not drawn to scale.

Published by Bioscientifica Ltd 
It has been found that in somatotrophs Gs transcript mainly derives from the maternal allele due to tissue-specific paternal imprinting (Hayward et al. 2001, Mantovani et al. 2002). The gsp mutations has been localized to the maternal allele in GH-secreting pituitary adenomas (Mantovani et al. 2004). In contrast, gsp-negative tumors mostly display biallelic expression of Gs (Picard et al. 2007), with a more relaxed imprinted pattern of expression. It is also worth noting that the gsp-negative adenomas expressing high levels of Gs show a clinical phenotype similar to that of $g s p$ positive tumors. Thus, not only activating mutations but also Gs $\alpha$ expression levels may have an effect on tumoral features of somatotroph adenomas.

The clinical phenotype of patients with loss of function mutations of GNAS1 points to a crucial role of cAMP in somatotroph differentiation and secretion. It is well known that heterozygous germ line GNAS1 mutations cause Albright hereditary osteodystrophy, a syndrome with a wide range of manifestations such as short stature, rounded facies, and often mild mental retardation, which, only when inherited from the mother, is defined as pseudohypoparathyroidism (PHP) type Ia, and associates with resistance to different hormones that act through Gs, e.g. parathyroid hormone, thyroid-stimulating hormone (TSH), and gonadotropins. Evidence indicates that this variable and tissue-specific hormone resistance may result from tissue-specific imprinting of the GNAS gene. Interestingly, it has been also observed that patients with PHP type Ia show resistance to growth hormone-releasing hormone (GHRH), resulting in short stature due to GH deficiency (Germain-Lee et al. 2003, Mantovani et al. 2003). These data demonstrate the clinical relevance of paternal imprinting of GNAS1 in selected endocrine glands, such as thyroid, gonads, and pituitary, which critically depend on cAMP for differentiation and functioning. As far as the pituitary is concerned, it is worth noting that in patients with PHP type Ia, the secretion of ACTH is normally controlled by $\mathrm{CRH}$, which acts via cAMP pathway activation, strongly suggesting that Gs $\alpha$ imprinting occurs in somatotrophs and not in corticotrophs.

\section{Alterations of the regulatory subunit of PKA (PRKAR1A) in endocrine disorders}

The role of cAMP in the control of cell proliferation has been further confirmed by the identification of PKA genetic defects in endocrine tumors.

Heterozygous loss of function mutations in human PKA regulatory subunit type Ia gene (PRKAR1A), located at 17q22-24, causing the loss of R1 expression and function with increased PKA responsiveness to cAMP, have been identified in about two-third of patients with Carney complex (CNC, MIM\# 160980), an autosomal dominant familial multiple neoplasia syndrome characterized by the presence of multiple cardiac and extracardiac myxomas, spotty skin pigmentation, and different endocrine tumors, including GH-secreting pituitary tumors, adrenocortical tumors, and thyroid adenomas (Carney et al. (1986), Casey et al. (2000) and Kirschner et al. (2000a,b), reviewed in Espiard \& Bertherat (2013)). More than 120 different PRKAR1A mutations localized in the entire coding sequence of the gene have been found, most of them leading to an unstable mRNA degraded by nonsense mediated mRNA decay. In vitro studies showed that PRKAR1A mutations stimulate PKA activity, mimicking constitutive activation of the cAMP signaling pathway. Moreover, pituitary tumorigenesis has been demonstrated in pituitary-specific PRKAR1A knock-out mice (Yin et al. 2008).

A reduced expression of PRKAR1A in GH-secreting adenomas in the absence of inactivating mutations has been reported (Lania et al. 2004). The low levels of this protein, due to an increased degradation by proteasomes, have been associated with an increase in proliferation of somatotrophs, in agreement with the effects of PRKAR1A mutations in $\mathrm{CNC}$ patients.

\section{Inactivating mutations of PDEs in patients with other cAMP-dependent lesions}

In adrenocortical lesions, including hyperplasia, adenomas, and cancer, and in testicular germ cell, tumors have been found caused by germline mutations of another gene involved in cAMP cascade, the most recently discovered PDE family member PDE11A (Fawcett et al. 2000, Horvath et al. 2006a,b).

These nonsense/missense PDE11A variants were also found in about a fifth of GH-secreting adenomas, with a frequency slightly higher with respect to controls (Peverelli et al. 2009a). However, in these tumors, the WT allele was maintained, with a consequent normal expression of this enzyme, and mutated patients showed no significant clinical phenotype, except a tendency toward greater tumor dimensions and suprasellar extension with respect to WT patients, suggesting that these variants might only marginally contribute to the development of somatotropinomas. Interestingly, PDE11A variants were associated with adrenal lesions with a frequency slightly higher than that for the WT, in agreement with the role of PDE11A in genetic predisposition to the development of adrenal tumors.

Published by Bioscientifica Ltd. 


\section{In vivo phenotype of gsp mutations: counteracting mechanism}

Despite the phenotype observed in transfected cell lines, where the $g s p$ oncogene confers a growth advantage, patients carrying this mutation have a similar clinical and biochemical phenotype to those who do not carry it. In particular, several screening studies carried out on large series of GH-secreting adenomas indicate no difference in age, sex, clinical features, GH and IGF1 levels, duration of the disease, cure rate, and outcome in patients with or without gsp mutations (Spada et al. 1990, Adams et al. 1993). On the other hand, gsp-positive tumors are frequently very small, well differentiated, and densely granulated, in agreement with their hypersecretory activity. Moreover, serum GH levels of patients with $g s p$ mutations are not further increased after GHRH stimulation, but respond to cAMP-independent stimuli, consistent with a constitutive Gs and adenylyl cyclase activation.

Finally, it is worth noting that $g s p$-positive tumors are characterized by an increased responsivity to treatment with SS analogs, a feature up to now unexplained, because no increases in SS receptors have been found in these tumors (Barlier et al. 1998, 1999, Corbetta et al. 2001). Overall, gsp mutations show a limited oncogenic potential and are associated with a benign phenotype. The only exception so far known existed in a lethal prolactinoma, in which $g s p$ mutation represented the second hit for the transition from prolactinoma to acromegaly (Lania et al. 2010).

This reduced oncogenic potential could be explained by the existence of intracellular regulatory mechanisms being able to counteract in vivo the activation of the cAMP pathway (Fig. 3).

First, the expression of $g s p$ oncogene is associated with activation of PDE that induces cAMP degradation. In $g s p$ positive GH-secreting adenomas, PDE activity was found to be about sevenfold higher than in WT tissues, this effect being mainly due to the increased expression of cAMPspecific PDE4 (Lania et al. 1998, Persani et al. 2001).

Second, the expression of CREB and inducible cAMP early repressor (ICER) is increased in tumors with $g s p$ mutations. As ICER competes with the binding of CREB to CRE and inhibits the transcription of cAMP-responsive genes, its upregulation may counteract the constitutive activation of the cAMP pathway (Peri et al. 2001).

Third, the presence of $g s p$ mutations strongly reduces the Gs $\alpha$ protein stability, as demonstrated by the analysis of Gs $\alpha$ in WT or mutated tumors. The low expression levels of Gs $\alpha$ found in $g s p$-positive adenomas is not due to a reduced transcription but rather to an increased degradation of the dissociated $\alpha$ subunit (Ballaré et al. 1998).

Furthermore, it should be considered that proliferation of somatotrophs may be inhibited independently of cAMP levels regulation. Although SS receptors are

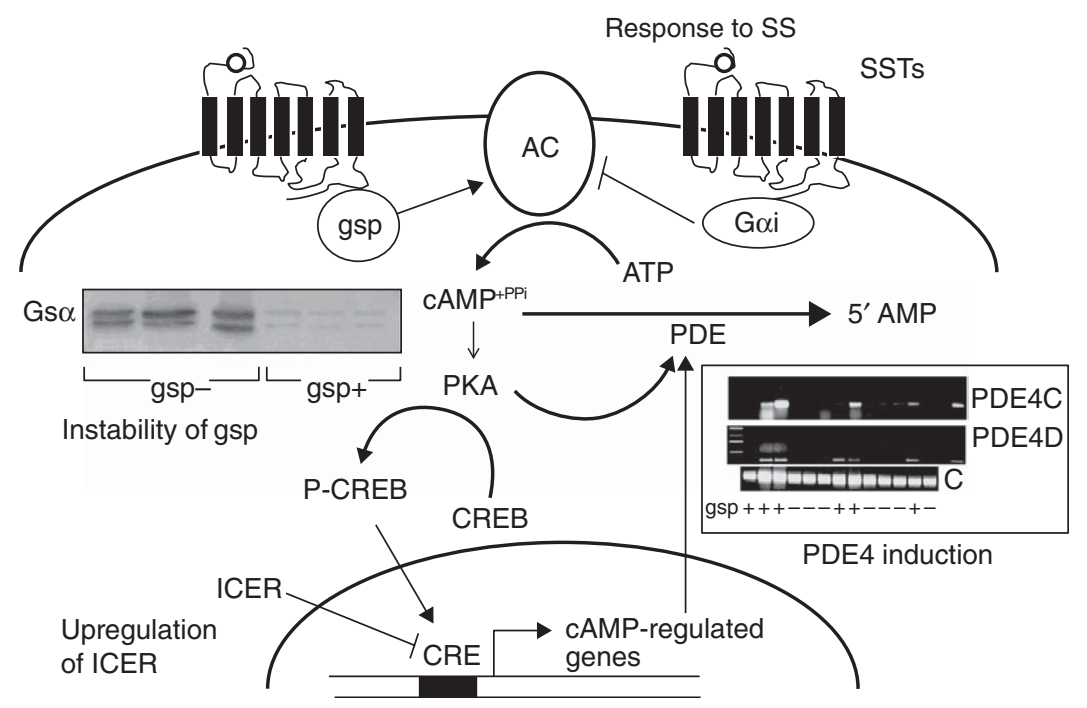

\section{Figure 3}

In vivo phenotype of gsp mutations and controregulatory mechanisms. The expression of the gsp oncogene is associated with significantly increased activity of PDE, particularly the CAMP-specific PDE4 isoform, with respect to WT tissues, this effect is mainly due to the increased expression of CAMPspecific PDE4C and PDE4D in gsp-positive tumors (+), as shown by RT-PCR analysis. The repressor transcription factor ICER is upregulated in gsp + more than in $g s p$ - adenomas. Moreover, gsp mutations are associated with instability of Gs $\alpha$ protein. Representative immunoblotting shows that $\mathrm{G} s \alpha$ protein is present in very low amount in $g s p+$ compared with gsp$\mathrm{GH}$-secreting adenomas. http://jme.endocrinology-journals.org DOI: 10.1530/JME-13-0172
(C) 2014 Society for Endocrinology Printed in Great Britain
Published by Bioscientifica Ltd 
coupled to inhibitory $G$ proteins that reduce cAMP formation by inhibiting adenylyl cyclase activity, it has recently been demonstrated that SST5, the most expressed SS receptor subtype in pituitary together with SST2, exerts its antiproliferative effects in somatotrophs by coupling with the inhibitory $G$ protein $\mathrm{Go}_{\mathrm{A}}$, independently of cAMP reduction (Peverelli et al. 2009b, 2013).

\section{Epac: new cAMP effectors}

Although all the effects exerted by cAMP were initially attributed to the activation of PKA, two exchange proteins directly activated by cAMP (Epac1/2) have been later identified as cAMP targets, which were able to mediate several cAMP effects by acting as guanine-nucleotide exchange factors for Ras-proximate 1 and 2 (Rap1 and 2) (Kawasaki et al. 1998, de Rooij et al. 1998). The two isoforms of Epac are coded in mammals by two distinct genes, RAPGEF3 and RAPGEF4. Epac 1 is ubiquitously expressed, whereas Epac 2 expression is restricted to a few tissues, including the brain, pituitary, adrenal gland, and pancreas.

Although the concentration of cAMP required for Epac1 protein activation in vitro was initially estimated to be about tenfold higher than that for PKA (Enserink et al. 2002), recent data indicate that Epac and PKA have similar affinity for cAMP, indicating that physiologically relevant cAMP concentrations are able to activate both enzymes (Dao et al. 2006).

In the endocrine system, few data are available about the specific role of Epac in mediating cAMP effects. Epac has been shown to be involved in cAMP-induced effects on cytoskeleton integrity and cell migration in adrenocortical cancer cells (Aumo et al. 2010), and crucial for TSH-induced stimulation of DNA synthesis and cell proliferation, acting synergistically with PKA in PCCL3, a normal TSHdependent rat thyroid follicular cell line (Hochbaum et al. 2008), although in dog thyrocytes none of the known cAMP-mediated TSH effects required Epac activation (Dremier et al. 2007). In pituitary, Epac is required for cAMP-dependent ERK1/2 activation in mouse pituitary AtT20 cells (Van Kolen et al. 2010) and implicated in the release of alpha melanocyte-stimulating hormone $(\alpha \mathrm{MSH})$ in mouse melanotrophs (Sedej et al. 2005). Preliminary unpublished data from our laboratory indicates that both Epac and PKA mediate the effects of cAMP on cell proliferation in different pituitary cell types.

The study of the relative roles of PKA and Epac in mediating cAMP effects in the pituitary will be of extreme importance for the identification of molecular mechanisms underlying the pathogenesis of pituitary tumors.

\section{Cross talk between CAMP and ERK signaling pathways}

The divergent effects of cAMP on cell proliferation are associated with its ability to positively or negatively regulate the MAPK signaling pathways, typically activated by growth factor receptors, with a resulting cross-talk between hormones acting through Gs $\alpha$-coupled receptors and growth factors.

The MAPK family includes serine/threonine kinases that transduce extracellular signals to intracellular responses, including cell proliferation, differentiation, migration, and apoptosis. The GTP-ase Ras, activated by growth factors, initiate a subsequent activation of a protein kinases cascade, involving Raf1, MEK, and ERK.

Several observations suggest that in pituitary, cAMP and MAPK pathways cross talk to regulate cell proliferation and hormone secretion. In somatolactotrope pituitary cells (GH4C1), the phosphorylation of ERK1/2 is stimulated by forskolin, which increases intracellular cAMP levels (Le Pechon-vallée et al. 2000). Similarly, in GH-secreting human pituitary tumors, GHRH and forskolin are able to activate ERK1/2 in a PKA-dependent manner, consistent with the mitogenic effects of cAMP in somatotrophs (Lania et al. 2003). In this cell model, the inhibition of the ERK cascade by the MEK inhibitor PD98059 abolished the GHRH-induced increase in cyclin D1, indicating that the stimulatory effect of PKA on the ERK1/2 cascade contributes to the proliferative action of cAMP.

Interestingly, in human pituitary tumors the Raf/ MEK/ERK pathway has been found to be upregulated (Dworakowska et al. 2009). Moreover, it has been demonstrated that conditional overexpression of both the WT Gs $\alpha$ or the $g s p$ oncogene initiates chronic ERK 1/2 activation (Romano et al. 2007). This sustained ERK1/2 stimulation might affect the tumoral phenotype despite the compensatory mechanisms of cAMP pathway.

Recently, using the fluorescence resonance energy transfer (FRET)-based biosensors of ERK activity (ERK activity reporter (EKAR)), it has been shown that both the EGF receptor and the GPCR coupled to cAMP stimulation, in particular the vasoactive intestinal peptide (VIP) receptor, to regulate the activation of ERK with different spatio-temporal dynamics (Zeiller et al. 2012). In particular, Ras and Rap1 play distinct roles in this process. EGF receptor induces nuclear ERK activation through Ras, which contribute to both cytoplasmic and nuclear ERK activation induced by VIP receptor. Rap1 plays a role in the activation of nuclear ERK stimulated by VIP receptor.

Published by Bioscientifica Ltd. 
The interrelationships between cAMP and ERK signaling pathways are multiple and complex. Several studies have suggested that the target of cAMP controlling ERK is downstream of Ras and upstream of Raf1. In particular, PKA inhibits Raf1 activity directly by phosphorylation or through Rap1 activation. Rap1 inhibits Ras signaling by blocking Ras binding to Raf1, in particular cell lines such as NIH3T3 cells (Schmitt \& Stork 2001). However, Rap1 can also activate the Raf isoform, B-Raf, leading to the ERK1/2 activation independently of Ras.

Although it has been shown that PKA in several cell systems may activate Rap1 indirectly by the guanine nucleotide exchange factor C3G, cAMP may also stimulate Rap1 activation through Epac activation, suggesting that PKA and Epac might synergistically control the cAMP-induced activation of the ERK1/2 pathway in pituitary cells.

\section{Cross talk between CAMP and calcium signaling pathways}

Hormone synthesis and secretion in pituitary are regulated by hypothalamic neuroendocrine regulatory factors that give rise to intracellular signaling cascades involving the two major second messengers, cAMP and calcium, which in turn are closely interconnected.

In somatotrophs, GHRH activates cAMP/PKA that, through the regulation of ion channels that results in increased calcium entry, stimulates GH secretion. In contrast, GH secretion is inhibited by SSTs both through activation of inhibitory $G$ proteins that reduce cAMP synthesis and regulation of L-type $\mathrm{Ca}^{2+}$ and $\mathrm{K}^{+}$channels with resulting reduction of calcium influx. In particular, SST5 inhibits GH release mainly through reduction of calcium entry, as demonstrated by the characterization of mutant SST5 receptors that were unable to reduce calcium influx and GH secretion even though they were still effective in inhibiting cAMP accumulation (Peverelli et al. 2009b).

Cross talk between the cAMP pathway and calcium signaling is bidirectional, because not only does cAMP regulate calcium influx, but also the cAMP pathway is influenced at different levels by calcium, with a regulatory mechanism that allows a mutual control of these two second messengers. Indeed, it has been demonstrated that calcium inhibits adenylyl cyclase in pituitary cells (Giannattasio et al. 1987), and influences PDE activity through the calcium-dependent regulator calmodulin (Ang \& Antoni 2002a,b), suggesting that changes in intracellular calcium levels contribute to the regulation of cAMP synthesis and degradation.

\section{Aryl hydrocarbon receptor interacting protein and the CAMP pathway}

Familial isolated pituitary adenoma (FIPA, MIM\# 102200) is an autosomal-dominant disease with variable penetrance, caused by germline mutations of the aryl hydrocarbon receptor (AHR)-interacting protein (AIP) gene (MIM\# 605555) (Benlian et al. 1995, Soares et al. 2005, Vierimaa et al. 2006). About $30 \%$ of all families with FIPA and $50 \%$ of families displaying acromegaly have a mutation in the AIP gene (Chahal et al. 2010), and AIPmutation-positive patients have a characteristic clinical phenotype with usually young- or childhood-onset GH and/or PRL-secreting adenomas.

However, the molecular mechanism whereby AIP induces pituitary tumorigenesis is unknown. Interestingly, it has been shown that among the proteins that interact with AIP there are members of the cAMP pathway. AIP has been demonstrated to bind PDE4A5, with consequent inhibition of its catalytic activity, attenuation of PDE4A5 phosphorylation by PKA, and increased sensitivity of PDE4A5 to rolipram, a PDE4-specific inhibitor, all these events leading to a decreased enzymatic activity. Naturally occurring AIP-truncating mutations completely abolish the interaction with PDE4A5 (Bolger et al. 2003, Leontiou et al. 2008, Igreja et al. 2010, Trivellin \& Korbonits 2011). Another PDE isoform, PDE2A, expressed in human pituitary (Lennox et al. 2011), has also been reported to bind to the C-terminal region of AIP and it has been shown that AIP has the opposite effect on PDE4A5 and PDE2A functions (de Oliveira et al. 2007, de Oliveira \& Smolenski 2009). Due to the central role of cAMP signaling in the pituitary, AIP interacting with PDEs may have an important role in AIP-related pituitary tumorigenesis, but up to now it is not clear whether PDEs binding correlates with the tumorigenic properties of AIP and what is the mechanism involved.

Recently it has been shown that in GH3 cells AIP regulates cAMP signaling and GH secretion independently of the AIP-PDE interaction (Formosa et al. 2013). The overexpression of the WT AIP, but not of a truncated mutant, reduces intracellular cAMP levels, the expression of cAMP target genes, and forskolin-induced GH secretion. Accordingly, knock down of endogenous AIP results in increased cAMP signaling, suggesting that AIP may act as a tumor suppressor by reducing cAMP signaling. Further studies are needed to clarify which binding partners and molecular mechanisms are involved.

Published by Bioscientifica Lto. 


\section{Is the action of CAMP in somatotrophs the paradigm of CAMP action in the pituitary?}

It is well known that cAMP either inhibits or stimulates cell proliferation and/or differentiation in a cell-typespecific manner (reviewed in Stork \& Schmitt (2002)) but, in contrast to the well recognized mitogenic effect of cAMP in the pituitary somatotrophs, the action of cAMP on the proliferation of pituitary cells of the other lineages has been poorly defined.

It has been demonstrated that in a subset of nonfunctioning pituitary adenomas (NFPA) that are mainly constituted by gonadotroph-derived cells, inhibition of the cAMP pathway is a proliferative signal. Indeed, PKA blockade by the specific inhibitor, PKI, increased cyclin D1 expression, whereas direct stimulation of adenylyl cyclase by forskolin resulted in a reduction in cyclin D1 expression (Mantovani et al. 2005). Moreover, in NFPAs the activation of PKC by specific neurohormones triggered the activation of mitogenic kinases, indicating the existence of different proliferative cascades specifically signaling in different pituitary cell lineages, i.e. tumoral somatotroph and gonadotroph-derived cells. Preliminary unpublished data from our laboratory indicates that, in analogy with the antiproliferative effects induced by cAMP in gonadotroph-derived cells previously reported (Mantovani et al. 2005), cAMP inhibits proliferation of cells of the lactotroph lineages.

The observation that the growth-promoting action of cAMP seems to occur exclusively in somatotrophs is in line with the notion that mutations activating cAMP formation or signaling are associated with the occurrence of sporadic or familial acromegaly, but not with other pituitary adenomas.

\section{Conclusions}

Despite extensive research on sporadic pituitary adenomas, the only molecular hallmarks of most GH-secreting adenomas up to now identified are the alterations, both genetic and epigenetic, of the GNAS gene, which have as a consequence the deregulation of the cAMP signaling cascade. The constitutive activation of the cAMP pathway is associated with the generation of a complex series of intracellular events that might either counteract cAMP action, such as increased sensitivity to somatostatin, instability of mutant Gs $\alpha$ protein, and induction of PDE expression, or cross talk with signals with oncogenic or anti-oncogenic potential, such as ERK, Epac, and AIP pathways. Although the gsp oncogene confers a growth advantage in an experimental in vitro model, tumors expressing $g s p$ mutations are well differentiated tumors, without any particular tendency to growth. Further studies are needed to understand the role of cAMP in pituitary cells other than somatotrophs.

Declaration of interest

The authors declare that there is no conflict of interest that could be perceived as prejudicing the impartiality of the review.

\section{Funding}

This work was partially supported by Associazione Italiana per la Ricerca sul Cancro, Milan (grant number MFAG 8972 to G M), by Progetti di Ricerca di Interesse Nazionale (PRIN) (grant number 2009YJTBAZ_004 to A G L), and by Ricerca Corrente Funds from the Fondazione Istituto di Ricerca e Cura a Carattere Scientifico (IRCCS) Ca' Granda-Milan (grant number 180-02 to A S).

\section{References}

Adams EF, Brockmeier S, Friedmann E, Roth M, Buchfelder M \& Fahlbusch R 1993 Clinical and biochemical characteristics of acromegalic patients harboring gsp-positive and gsp-negative pituitary tumors. Neurosurgery 33 198-203. (doi:10.1227/00006123-199308000-00003)

Ang KL \& Antoni FA 2002a Reciprocal regulation of calcium dependent and calcium independent cyclic AMP hydrolysis by protein phosphorylation. Journal of Neurochemistry $\mathbf{8 1}$ 422-433. (doi:10.1046/j.1471-4159. 2002.00903.x)

Ang KL \& Antoni FA $2002 b$ Functional plasticity of cyclic AMP hydrolysis in rat adenohypophysial corticotroph cells. Cellular Signalling 14 445-452. (doi:10.1016/S0898-6568(01)00267-4)

Antoni FA, Sosunov AA, Haunso A, Paterson JM \& Simpson J 2003 Shortterm plasticity of cyclic adenosine $3^{\prime}, 5^{\prime}$-monophosphate signaling in anterior pituitary corticotrope cells: the role of adenylyl cyclase isotypes. Molecular Endocrinology 17 692-703. (doi:10.1210/me.2002-0369)

Aumo L, Rusten M, Mellgren G, Bakke M \& Lewis AE 2010 Functional roles of protein kinase A (PKA) and exchange protein directly activated by $3^{\prime}, 5^{\prime}$-cyclic adenosine $5^{\prime}$-monophosphate (cAMP) 2 (EPAC2) in cAMPmediated actions in adrenocortical cells. Endocrinology 151 2151-2161. (doi:10.1210/en.2009-1139)

Ballaré E, Mantovani S, Lania A, Di Blasio AM, Vallar L \& Spada A 1998 Activating mutations of the $\mathrm{G}_{\mathrm{s}} \alpha$ gene are associated with low levels of Gs $\alpha$ protein in growth hormone-secreting tumors. Journal of Clinical Endocrinology and Metabolism 83 4386-4390. (doi:10.1210/ jc.83.12.4386)

Barlier A, Gunz G, Zamora AJ, Morange-Ramos I, Figarella-Branger D, Dufour H, Enjalbert A \& Jaquet P 1998 Pronostic and therapeutic consequences of $\mathrm{G}_{\mathrm{s}} \alpha$ mutations in somatotroph adenomas. Journal of Clinical Endocrinology and Metabolism 83 1604-1610. (doi:10.1210/jc. 83.5.1604)

Barlier A, Pellegrini-Bouiller I, Gunz G, Zamora AJ, Jaquet P \& Enjalbert A 1999 Impact of $g s p$ oncogene on the expression of genes coding for $\mathrm{G}_{\mathrm{s}} \alpha$, Pit-1, $\mathrm{G}_{\mathrm{i}} 2 \alpha$, and somatostatin receptor 2 in human somatotroph adenomas: involvement in octreotide sensitivity. Journal of Clinical Endocrinology and Metabolism 84 2759-2765. (doi:10.1210/jc.84.8.2759)

Bartolomei MS \& Tilgham SM 1997 Genomic imprinting in mammals. Annual Review of Genetics 31 493-525. (doi:10.1146/annurev.genet. 31.1.493)

Bastepe M \& Juppner H 2005 GNAS locus and pseudohypoparathyroidism. Hormone Research 63 65-74. (doi:10.1159/000083895) http://jme.endocrinology-journals.org DOI: 10.1530/JME-13-0172
C 2014 Society for Endocrinology Printed in Great Britain 
Bender AT \& Beavo JA 2006 Cyclic nucleotide phosphodiesterases: molecular regulation to clinical use. Pharmacological Reviews 58 488-520. (doi:10.1124/pr.58.3.5)

Benlian P, Giraud S, Lahlou N, Roger M, Blin C, Holler C, Lenoir G, Sallandre J, Calender A \& Turpin G 1995 Familial acromegaly: a specific clinical entity - further evidence from the genetic study of a threegeneration family. European Journal of Endocrinology 133 451-456. (doi:10.1530/eje.0.1330451)

Bolger GB, Peden AH, Steele MR, MacKenzie C, McEwan DG, Wallace DA, Huston E, Baillie GS \& Houslay MD 2003 Attenuation of the activity of the cAMP-specific phosphodiesterase PDE4A5 by interaction with the immunophilin XAP2. Journal of Biological Chemistry $27833351-33363$. (doi:10.1074/jbc.M303269200)

Carney JA, Hruska L, Beauchamp GD \& Gordon H 1986 Dominant inheritance of the complex of myxomas, spotty pigmentation and endocrine overactivity. Mayo Clinic Proceedings 61 165-172. (doi:10.1016/S0025-6196(12)61843-6)

Casey M, Vaughan CJ, He J, Hatcher CJ, Winter JM, Weremowicz S, Montgomery K, Kucherlapati R, Morton CC \& Basson CT 2000 Mutations in the protein kinase A R $1 \alpha$ regulatory subunit cause familial myxomas and Carney complex. Journal of Clinical Investigation 106 R31-R38. (doi:10.1172/JCI10841)

Chahal HS, Chapple JP, Frohman LA, Grossman AB \& Korbonits M 2010 Clinical, genetic and molecular characterization of patients with familial isolated pituitary adenomas (FIPA). Trends in Endocrinology and Metabolism 21 419-427. (doi:10.1016/j.tem.2010.02.007)

Clementi E, Malgaretti N, Meldolesi J \& Taramelli R 1990 A new constitutively activating mutation of the Gs protein $\alpha$ subunit-gs $p$ oncogene is found in human pituitary tumours. Oncogene 5 1059-1061.

Corbetta S, Ballare E, Mantovani G, Lania A, Losa M, Di Blasio AM \& Spada A 2001 Somatostatin receptor subtype 2 and 5 in human GH-secreting pituitary adenomas: analysis of gene sequence and mRNA expression. European Journal of Clinical Investigation 31 208-214. (doi:10.1046/ j.1365-2362.2001.00786.x)

Dao KK, Teigen K, Kopperud R, Hodneland E, Schwede F, Christensen AE, Martinez A \& Døskeland SO 2006 Epac1 and cAMP-dependent protein kinase holoenzyme have similar cAMP affinity, but their cAMP domains have distinct structural features and cyclic nucleotide recognition. Journal of Biological Chemistry $28121500-21511$. (doi:10.1074/jbc.M603116200)

Dremier S, Milenkovic M, Blancquaert S, Dumont JE, Døskeland SO, Maenhaut C \& Roger PP 2007 Cyclic adenosine 3',5'-monophosphate (cAMP)-dependent protein kinases, but not exchange proteins directly activated by cAMP (Epac), mediate thyrotropin/cAMP-dependent regulation of thyroid cells. Endocrinology 148 4612-4622. (doi:10.1210/ en.2007-0540)

Dworakowska D, Wlodek E, Leontiou CA, Igreja S, Cakir M, Teng M, Prodromou N, Góth MI, Grozinsky-Glasberg S, Gueorguiev M et al. 2009 Activation of RAF/MEK/ERK and PI3K/AKT/mTOR pathways in pituitary adenomas and their effects on downstream effectors. Endocrine-Related Cancer 16 1329-1338. (doi:10.1677/ERC-09-0101)

EnserinkJM, Christensen AE, de RooijJ, van Triest M, Schwede F, Genieser HG, Døskeland SO, Blank JL \& Bos JL 2002 A novel Epac-specific cAMP analogue demonstrates independent regulation of Rap1 and ERK. Nature Cell Biology 4 901-906. (doi:10.1038/ncb874)

Espiard S \& Bertherat J 2013 Carney complex. Frontiers of Hormone Research 41 50-62. (doi:10.1159/000345669)

Fawcett L, Baxendale R, Stacey P, McGrouther C, Harrow I, Soderling S, Hetman J, Beavo JA \& Phillips SC 2000 Molecular cloning and characterization of a distinct human phosphodiesterase gene family: PDE11A. PNAS 97 3702-3707. (doi:10.1073/pnas.97.7.3702)

Formosa R, Xuereb-Anastasi A \& Vassallo J 2013 Aip regulates cAMP signalling and GH secretion in GH3 cells. Endocrine-Related Cancer 20 495-505. (doi:10.1530/ERC-13-0043)

Germain-Lee EL, Groman J, Crane JL, Jan de Beur SM \& Levine MA 2003 Growth hormone deficiency in pseudohypoparathyroidism type 1a: another manifestation of multihormone resistance. Journal of Clinical Endocrinology and Metabolism 88 4059-4069. (doi:10.1210/ jc.2003-030028)

Giannattasio G, Bianchi R, Spada A \& Vallar L 1987 Effect of calcium on adenylate cyclase of rat anterior pituitary gland. Endocrinology $\mathbf{1 2 0}$ 2611-2619. (doi:10.1210/endo-120-6-2611)

Ham J, Ivan M, Wynford-Thomas D \& Scanlon MF 1997 GH3 expressing constitutively active Gs $\alpha$ (Q227L) show enhanced hormone secretion and proliferation. Molecular and Cellular Endocrinology 127 41-47. (doi:10.1016/S0303-7207(96)03987-1)

Hayward BE, Barlier A, Korbonits M, Grossman AB, Jacquet P, Enjalbert A \& Bonthron DT 2001 Imprinting of the $\mathrm{G}_{\mathrm{s}} \alpha$ gene GNAS1 in the pathogenesis of acromegaly. Journal of Clinical Investigation $\mathbf{1 0 7}$ R31-R36. (doi:10.1172/JCI11887)

Hochbaum D, Hong K, Barila G, Ribeiro-Neto F \& Altschuler DL 2008 Epac, in synergy with cAMP-dependent protein kinase (PKA), is required for cAMP-mediated mitogenesis. Journal of Biological Chemistry $\mathbf{2 8 3}$ 4464-4468. (doi:10.1074/jbc.C700171200)

Horvath A, Boikos S, Giatzakis C, Robinson-White A, Groussin L, Griffin KJ, Stein E, Levine E, Delimpasi G, Hsiao HP et al. 2006 a A genome-wide scan identifies mutations in the gene encoding phosphodiesterase 11A4 (PDE11A) in individuals with adrenocortical hyperplasia. Nature Genetics 38 794-800. (doi:10.1038/ng1809)

Horvath A, Giatzakis C, Robinson-White A, Boikos S, Levine E, Griffin K, Stein E, Kamvissi V, Soni P, Bossis I et al. 2006b Adrenal hyperplasia and adenomas are associated with inhibition of phosphodiesterase $11 \mathrm{~A}$ in carriers of $P D E 11 A$ sequence variants that are frequent in the population. Cancer Research 66 11571-11575. (doi:10.1158/0008-5472. CAN-06-2914)

Igreja S, Chahal HS, King P, Bolger GB, Srirangalingam U, Guasti L, Chapple JP, Trivellin G, Gueorguiev M, Guegan K et al. 2010 Characterization of aryl hydrocarbon receptor interacting protein (AIP) mutations in familial isolated pituitary adenoma families. Human Mutation 31 950-960. (doi:10.1002/humu.21292)

Kawasaki H, Springett GM, Mochizuki N, Toki S, Nakaya M, Matsuda M, Housman DE \& Graybiel AM 1998 A family of cAMP-binding proteins that directly activate Rap1. Science 282 2275-2279. (doi:10.1126/ science.282.5397.2275)

Kirschner LS, Carney JA, Pack SD, Taymans SE, Giatzakis C, Cho YS, Cho-Chung YS \& Stratakis CA 2000a Mutations of the gene encoding the protein kinase A type I- $\alpha$ regulatory subunit in patients with the Carney complex. Nature Genetics 26 89-92. (doi:10.1038/79238)

Kirschner LS, Sandrini F, Monbo J, Lin JP, Carney JA \& Stratakis CA $2000 b$ Genetic heterogeneity and spectrum of mutations of the PRKAR1A gene in patients with the Carney complex. Human Molecular Genetics 9 3037-3046. (doi:10.1093/hmg/9.20.3037)

Landis CA, Masters SB, Spada A, Pace AM, Bourne HR \& Vallar L 1989 GTPase inhibiting mutations activate the $\alpha$ chain of Gs and stimulate adenylyl cyclase in human pituitary tumours. Nature 340 692-696. (doi:10.1038/340692a0)

Lania A, Persani L, Ballare E, Mantovani S, Losa M \& Spada A 1998 Constitutively active Gs $\alpha$ is associated with an increased phosphodiesterase activity in human growth hormone-secreting adenomas. Journal of Clinical Endocrinology and Metabolism 83 1624-1628. (doi:10.1210/jc.83.5.1624)

Lania A, Filopanti M, Corbetta S, Losa M, Ballaré E, Beck-Peccoz P \& Spada A 2003 Effects of hypothalamic neuropeptides on extracellular signalregulated kinase (ERK1 and ERK2) cascade in human tumoral pituitary cells. Journal of Clinical Endocrinology and Metabolism 88 1692-1696. (doi:10.1210/jc.2002-021207)

Lania AG, Mantovani G, Ferrero S, Pellegrini C, Bondioni S, Peverelli E, Braidotti P, Locatelli M, Zavanone ML, Ferrante E et al. 2004 Proliferation of transformed somatotroph cells related to low or absent expression of protein kinase a regulatory subunit $1 \mathrm{~A}$ protein. Cancer Research 64 9193-9198. (doi:10.1158/0008-5472.CAN-04-1847) 
Lania AG, Ferrero S, Pivonello R, Mantovani G, Peverelli E, Di Sarno A, Beck-Peccoz P, Spada A \& Colao A 2010 Evolution of an aggressive prolactinoma into a growth hormone secreting pituitary tumor coincident with GNAS gene mutation. Journal of Clinical Endocrinology and Metabolism 95 13-17. (doi:10.1210/jc.2009-1360)

Lennox CA, Trivellin G \& Korbonits M 2011 Evaluation of the interaction of phosphodiesterases $2 \mathrm{~A}$ and $4 \mathrm{~A} 5$ with the aryl hydrocarbon receptor interacting protein in pituitary cells. Endocrine Abstracts 25 P245.

Leontiou CA, Gueorguiev M, van der Spuy J, Quinton R, Lolli F, Hassan S, Chahal HS, Igreja SC, Jordan S \& Rowe J 2008 The role of the aryl hydrocarbon receptor-interacting protein gene in familial and sporadic pituitary adenomas. Journal of Clinical Endocrinology and Metabolism 93 2390-2401. (doi:10.1210/jc.2007-2611)

Le Péchon-Vallée C, Magalon K, Rasolonjanahary R, Enjalbert A \& Gérard C 2000 Vasoactive intestinal polypeptide and pituitary adenylate cyclaseactivating polypeptides stimulate mitogen-activated protein kinase in the pituitary cell line GH4C1 by a $3^{\prime}, 5^{\prime}$-cyclic adenosine monophosphate pathway. Neuroendocrinology 72 46-56. (doi:10.1159/000054570)

Lyons J, Landis CA, Harsh G, Vallar L, Grunwald K, Feichtinger H, Duh QY, Clark OH, Kawasaki E, Bourne HR et al. 1990 Two G protein oncogenes in human endocrine tumors. Science 249 655-659. (doi:10.1126/ science.2116665)

Mantovani G, Ballare E, Giammona E, Beck-Peccoz P \& Spada A 2002 The Gs $\alpha$ gene: predominant maternal origin of transcription in human thyroid gland and gonads. Journal of Clinical Endocrinology and Metabolism 87 4736-4740. (doi:10.1210/jc.2002-020183)

Mantovani G, Maghnie M, Weber G, De Menis E, Brunelli V, Cappa M, Loli P, Beck-Peccoz P \& Spada A 2003 Growth hormone-releasing hormone resistance in pseudohypoparathyroidism type Ia: new evidence for imprinting of the Gs $\alpha$ gene. Journal of Clinical Endocrinology and Metabolism 88 4070-4074. (doi:10.1210/jc.2002-022028)

Mantovani G, Bondioni S, Lania AG, Corbetta S, de Sanctis L, Cappa M, Di Battista E, Chanson P, Beck-Peccoz P \& Spada A 2004 Parental origin of $\mathrm{G}_{\mathrm{s}} \alpha$ mutations in the McCune-Albright syndrome and in isolated endocrine tumors. Journal of Clinical Endocrinology and Metabolism 89 3007-3009. (doi:10.1210/jc.2004-0194)

Mantovani G, Bondioni S, Ferrero S, Gamba B, Ferrante E, Peverelli E, Corbetta S, Locatelli M, Rampini P, Beck-Peccoz P et al. 2005 Effect of cyclic adenosine $3^{\prime}, 5^{\prime}$-monophosphate/protein kinase a pathway on markers of cell proliferation in nonfunctioning pituitary adenomas. Journal of Clinical Endocrinology and Metabolism 90 6721-6724. (doi:10.1210/jc.2005-0977)

Michibata H, Yanaka N, Kanoh Y, Okumura K \& Omori K 2001 Human $\mathrm{Ca}^{2+} /$ calmodulin-dependent phosphodiesterase PDE1A: novel splice variants, their specific expression, genomic organization, and chromosomal localization. Biochimica et Biophysica Acta 1517 278-287. (doi:10.1016/S0167-4781(00)00293-1)

Muca C \& Vallar L 1994 Expression of mutationally activated Gas stimulates growth and differentiation of thyroid FRTL 5 cells. Oncogene 9 3647-3653.

de Oliveira SK \& Smolenski A 2009 Phosphodiesterases link the aryl hydrocarbon receptor complex to cyclic nucleotide signaling. Biochemical Pharmacology 77 723-733. (doi:10.1016/j.bcp.2008.08.027)

de Oliveira SK, Hoffmeister M, Gambaryan S, Muller-Esterl W, Guimaraes JA \& Smolenski AP 2007 Phosphodiesterase 2A forms a complex with the co-chaperone XAP2 and regulates nuclear translocation of the aryl hydrocarbon receptor. Journal of Biological Chemistry 282 13656-13663. (doi:10.1074/jbc.M610942200)

Paulssen RH, Johansen PW, Gordeladze JO, Nymoen O, Paulssen EJ \& Gautvik KM 1994 Cell-specific expression and function of adenylyl cyclases in rat pituitary tumour cell lines. European Journal of Biochemistry 222 97-103. (doi:10.1111/j.1432-1033.1994.tb18846.x)

Peri A, Conforti B, Baglioni-Peri S, Luciani P, Cioppi F, Buci L, Corbetta S, Ballaré E, Serio M \& Spada A 2001 Expression of cyclic adenosine 3',5'-monophosphate (cAMP)-responsive element binding protein and inducible cAMP early repressor genes in growth hormone-secreting pituitary adenomas with or without mutations of the Gs $\alpha$ gene. Journal of Clinical Endocrinology and Metabolism 86 2111-2117. (doi:10.1210/jc.86.5.2111)

Persani L, Lania A, Borgato S, Filopanti M, Mantovani G, Conti M \& Spada A 2001 Relevant cAMP-specific phosphodiesterase isoforms in human pituitary: effect of Gs $\alpha$ mutations. Journal of Clinical Endocrinology and Metabolism 86 3795-3800. (doi:10.1210/jc.86.8.3795)

Peverelli E, Ermetici F, Filopanti M, Elli FM, Ronchi CL, Mantovani G, Ferrero S, Bosari S, Beck-Peccoz P, Lania A et al. 2009a Analysis of genetic variants of phosphodiesterase $11 \mathrm{~A}$ in acromegalic patients. European Journal of Endocrinology 161 687-694. (doi:10.1530/EJE-09-0677)

Peverelli E, Lania AG, Mantovani G, Beck-Peccoz P \& Spada A 2009 b Characterization of intracellular signaling mediated by human somatostatin receptor 5: role of the DRY motif and the third intracellular loop. Endocrinology 150 3169-3176. (doi:10.1210/en.2008-1785)

Peverelli E, Busnelli M, Vitali E, Giardino E, Galés C, Lania AG, Beck-Peccoz P, Chini B, Mantovani G \& Spada A 2013 Specific roles of Gi protein family members revealed by dissecting somatostatin receptor 5 (SST5) coupling in human pituitary cells. Journal of Cell Science 126 638-644. (doi:10. 1242/jcs.116434)

Picard C, Silvy M, Gerard C, Buffat C, Lavaque E, Figarella-Branger D, Dufour H, Gabert J, Beckers A, Brue T et al. 2007 Gs $\alpha$ overexpression and loss of Gs $\alpha$ imprinting in human somatotroph adenomas: association with tumor size and response to pharmacologic treatment. International Journal of Cancer 121 1245-1252. (doi:10.1002/ijc.22816)

Pronko SP, Saba LM, Hoffman PL \& Tabakoff B 2010 Type 7 adenylyl cyclase-mediated hypothalamic-pituitary-adrenal axis responsiveness: influence of ethanol and sex. Journal of Pharmacology and Experimental Therapeutics 334 44-52. (doi:10.1124/jpet.110.166793)

Romano D, Magalon K, Pertuit M, Rasolonjanahary R, Barlier A, Enjalbert A $\&$ Gerard C 2007 Conditional overexpression of the wild type $G_{s} \alpha$ as the gsp oncogene initiates chronic extracellulary regulated kinase $1 / 2$ activation and hormone hypersecretion in pituitary cell lines. Endocrinology 148 2973-2983. (doi:10.1210/en.2006-1273)

de Rooij J, Zwartkruis FJ, Verheijen MH, Cool RH, Nijman SM, Wittinghofer A \& Bos JL 1998 Epac is a Rap1 guanine-nucleotide-exchange factor directly activated by cyclic AMP. Nature 396 474-477. (doi:10.1038/24884)

Schmitt JM \& Stork PJ 2001 Cyclic AMP-mediated inhibition of cell growth requires the small G protein Rap1. Molecular and Cellular Biology 21 3671-3683. (doi:10.1128/MCB.21.11.3671-3683.2001)

Schwindinger WF, Francomano CA \& Levine MA 1992 Identification of a mutation in the gene encoding the a subunit of the stimulatory G-protein of adenylyl cyclase in McCune-Albright syndrome. PNAS $\mathbf{8 9}$ 5152-5156. (doi:10.1073/pnas.89.11.5152)

Sedej S, Rose T \& Rupnik MJ 2005 cAMP increases $\mathrm{Ca}^{2+}$-dependent exocytosis through both PKA and Epac2 in mouse melanotrophs from pituitary tissue slices. Physiology 567 799-813. (doi:10.1113/jphysiol. 2005.090381)

Skalhegg BS \& Tasken K 2000 Specificity in the cAMP/PKA signaling pathway. Differential expression, regulation, and subcellular localization of subunits of PKA. Frontiers in Bioscience 5 D678-D693. (doi:10.2741/Skalhegg)

Soares BS, Eguchi K \& Frohman LA 2005 Tumor deletion mapping on chromosome 11q13 in eight families with isolated familial somatotropinoma and in 15 sporadic somatotropinomas. Journal of Clinical Endocrinology and Metabolism 90 6580-6587. (doi:10.1210/jc.2005-1478)

Spada A, Arosio M, Bochicchio D, Bazzoni N, Vallar L, Bassetti M \& Faglia G 1990 Clinical, biochemical and morphological correlates in patients bearing growth hormone secreting tumors with or without constitutively active adenylyl cyclase. Journal of Clinical Endocrinology and Metabolism 71 1421-1426. (doi:10.1210/jcem-71-6-1421)

Stephenson DT, Coskran TM, Wilhelms MB, Adamowicz WO, O'Donnell MM, Muravnick KB, Menniti FS, Kleiman RJ \& Morton D 2009 Immunohistochemical localization of phosphodiesterase $2 \mathrm{~A}$ in multiple mammalian species. Journal of Histochemistry and Cytochemistry 57 933-949. (doi:10.1369/jhc.2009.953471) 
Stork PJ \& Schmitt JM 2002 Crosstalk between cAMP and MAP kinase signaling in the regulation of cell proliferation. Trends in Cell Biology 12 258-266. (doi:10.1016/S0962-8924(02)02294-8)

Sunahara RK \& Taussig R 2002 Isoforms of mammalian adenylyl cyclase: multiplicities of signaling. Molecular Interventions 2 168-184. (doi:10.1124/mi.2.3.168)

Trivellin G \& Korbonits M 2011 AIP and its interacting partners. Journal of Endocrinology 210 137-155. (doi:10.1530/JOE-11-0054)

Vallar L, Spada A \& Giannattasio G 1987 Altered Gs and adenylate cyclase activity in human GH-secreting pituitary adenomas. Nature 330 566-568. (doi:10.1038/330566a0)

Van Kolen K, Dautzenberg FM, Verstraeten K, Royaux I, De Hoogt R, Gutknecht E \& Peeters PJ 2010 Corticotropin releasing factor-induced ERK phosphorylation in AtT20 cells occurs via a cAMP-dependent mechanism requiring EPAC2. Neuropharmacology 58 135-144. (doi:10.1016/j.neuropharm.2009.06.022)

Vierimaa O, Georgitsi M, Lehtonen R, Vahteristo P, Kokko A, Raitila A, Tuppurainen K, Ebeling TM, Salmela PI, Paschke R et al. 2006 Pituitary adenoma predisposition caused by germline mutations in the AIP gene. Science 312 1228-1230. (doi:10.1126/science.1126100)

Wachten S, Masada N, Ayling LJ, Ciruela A, Nikolaev VO, Lohse MJ \& Cooper DM 2010 Distinct pools of cAMP centre on different isoforms of adenylyl cyclase in pituitary-derived GH3B6 cells. Journal of Cell Science 123 95-106. (doi:10.1242/jcs.058594)

Weinstein LS, Shenker A, Gejman P, Marino MJ, Friedman E \& Spiegel AM 1991 Activating mutations of the stimulatory $G$ protein in the McCune-Albright syndrome. New England Journal of Medicine 325 1688-1695. (doi:10.1056/NEJM199112123252403)

Wilson CH, McIntyre RE, Arends MJ \& Adams DJ 2010 The activating mutation R201C in GNAS promotes intestinal tumourigenesis in $\mathrm{Apc}^{\mathrm{Min} /+}$ mice through activation of Wnt and ERK1/2 MAPK pathways. Oncogene 29 4567-4575. (doi:10.1038/onc.2010.202)

Yin Z, Williams-Simons L, Parlow AF, Asa S \& Kirschner LS 2008 Pituitaryspecific knockout of the Carney complex gene Prkar1a leads to pituitary tumorigenesis. Molecular Endocrinology 22 380-387. (doi:10.1210/ me.2006-0428)

Zachary I, Masters SB \& Bourne HR 1990 Increased mitogenic responsiveness of Swiss 3T3 cells expressing constitutively active Gs $\alpha$. Biochemical and Biophysical Research Communications 168 1184-1193. (doi:10.1016/ 0006-291X(90)91154-K)

Zeiller C, Blanchard MP, Pertuit M, Thirion S, Enjalbert A, Barlier A \& Gerard C 2012 Ras and Rap1 govern spatio temporal dynamic of activated ERK in pituitary living cells. Cellular Signalling 24 2237-2248. (doi:10.1016/j.cellsig.2012.08.006)

Received in final form 13 September 2013

Accepted 18 September 2013

Accepted Preprint published online 18 September 2013 http://jme.endocrinology-journals.org DOI: 10.1530/JME-13-0172
(C) 2014 Society for Endocrinology Printed in Great Britain
Published by Bioscientifica Ltd. 